\title{
THE HEGEMONY OF ENGLISH IN PUBLIC DISCOURSE
}

\author{
E. Yohanita Irene \\ English Department, Faculty of Humanities, Bina Nusantara University \\ Jln. Kemanggisan Ilir III No.45, Kemanggisan - Palmerah, Jakarta 11480 \\ nita88nita@yahoo.com
}

\begin{abstract}
This article looks at the relation of the global role of English to the English hegemony found in the Jakarta Post articles. It highlights the readers' point of view, specifically the arguments they used in opposing the Education and Culture Ministry plan to scrap English from Elementary School Curriculum. It underlines the contemporary phenomenon of English as a world language and the role it plays in contributing to the dominance of English reflected on the readers' opinion.
\end{abstract}

Keywords: hegemony, English, public discourse

\begin{abstract}
ABSTRAK
Artikel menjelaskan hubungan peran global bahasa Inggris dengan hegemoni bahasa Inggris yang dimuat pada artikel koran Jakarta Post. Artikel mengungkapkan pandangan pembaca, terutama argumen mereka terhadap rencana Kementerian Pendidikan dan Kebudayaan untuk menghapuskan mata pelajaran bahasa Inggris pada kurikulum Sekolah Dasar. Menurut pendapat pembaca, hal ini berlawanan dengan fenomena bahasa Inggris sebagai bahasa dunia dan juga peran bahasa Inggris tersebut pada dominansi bahasa Inggris.
\end{abstract}

Kata kunci: hegemoni, Bahasa Inggris, diskursus publik 


\section{INTRODUCTION}

As part of the government's plan to revise the national curriculum that will be implemented next school year, English will no longer be a subject taught in elementary schools. The Deputy Education and Culture Minister, Musliar Kaslim, stated that the omission intended to give more than enough time for students to master the Indonesian language first before submerging into foreign languages (The Jakarta Post, 2012). The plan raises pros and cons among the readers.

In Indonesia, the notion that English is in fact has become the essential cornerstone which plays a dominant position in education is specifically shown by the phenomenon of the teaching of English starting in early childhood education level. The teaching of English in kindergarten level indicates that English has become a "basic skill" learnt by younger children, rather than something that older children or adults might want to acquire later. This phenomenon, however, with the assumption that children haven't learnt to understand the Indonesian language yet, is one of the concerns stated by the Deputy Education and Culture Minister when reasoning the plan of omitting English from primary school.

English is no longer only of concern to the people living in Britain, United States or Australia, but it is now entrenched worldwide, as a neo-colonialism power. Neocolonialism, which constitutes the policy where a major power uses economic or political, means to exert its influence over undeveloped nations or areas to gain control. The control over the nations could be economic, cultural or linguistic and can be demonstrated simply by larger powers promoting their own culture in these independent nations.

Phillipson (2003:48) writes, "In the contemporary world, English Language Teaching seems to be marketable worldwide. There is a demand for material products and resources (books, jobs for English teachers, space on timetables) and for immaterial resources (ideas, teaching principles)." This is of significance to Britain, as the Director-General of the British Council stated in the 1987/88 Annual Report (page 8): "Britain's real black gold is not North Sea oil but the English language. It has long been the root of our culture and now it fast becoming the global language of business and information. The challenge facing us is to exploit it to the full." (Ibid).

This article firstly attempts to look at the authors' point of view, specifically the arguments they used in opposing the Education and Culture Ministry plan to scrap English from Elementary School Curriculum. Secondly, it attempts to see the relation of the global role of English to the English hegemony found in the articles.

The research questions that will be explored in the article are what arguments have been used to justify the need of learning English in Elementary School?, and how can one, in a theoretically informed way, relate the global role of English to the English hegemony? In order to provide a basis for tentative answers to the research questions, the literature review presents the theoretical framework for the analysis. This part deals with the theory of English hegemony.

'Hegemony' means the success of the dominant classes in presenting their definition of reality, their view of the world, in such a way that it is accepted by other classes as 'common sense'. The general 'consensus' is that it is the only sensible way of seeing the world. Any groups who present an alternative view are therefore marginalized. (Goldberg, n.d.).

English hegemony, as the manifestation of linguistic imperialism, has spread globally, which indicates the dominant status of English as the most commonly used language today. Ammon (1992:78-81) points out the dominance of English by providing same statistics about the dominance of English. According to him, (1) English has the greatest number of speakers reaching as many as 1.5 billion people; (2) English is designated as official languages of as many as 62 nations; (3) English is the most dominant language in scientific communication with 70-80 percent of academic publications being published in it; (4) English is the de facto official and working language in most international organizations; (5) English is the most taught foreign language across the world.

Burchfield (1985:160) states: "English has also become a lingua franca to the point that any literate educated person is in a very real sense deprived if he does not know English." The dominance of English, in fact, also creates discriminatory prejudices against who can't speak English considered incompetent and inferior. For instance, people who write up their research in languages other than English probably will have their work ignored by the international community. Moreover, textbooks written in English are used in virtually almost all university degree programs, which imply that English is a pre-condition for higher educational qualifications.

Nevertheless, this domination, according to Tisci (n.d.), is not a recent product of the globalization, but it is the result of the political, economic, military and cultural power of English speakers in the history. Crystal (2003) underlines that this status occurs neither because today English is the language most taught as a foreign language and the official language in over seventy countries, nor because of the simplicity of its grammar, like somebody believes. The adjective is rather due to the fact that English is the current language of the diplomatic and economic relationships, of the academic world and of the cultural industry. These are all domains that, especially at this moment of large globalization, need an international language. Hence, from this point of view, it is clear that "English was in the right place at the right time" (Crytal, 2003:46).

\section{METHOD}

The research analyses some articles on The Jakarta Post Readers Forum and Opinion. There are three articles to be analysed, which highlight the disagreement to the omission of English from Elementary school curriculum. The analysis undertaken here serves to illustrate the English hegemony in the context of the three texts. The paper concludes with a brief summary of the results and some reflections on proposed counter-strategy to the English hegemony, before considering some possible next steps for future research. 


\section{RESULTS AND DISCUSSION}

Couple of days after The Jakarta Post reported an interview with The Deputy Education and Culture Minister for Education, Musliar Kasim, about the omission of English from Elementary school as part of the new curriculum effective next school year; there were quite strong reactions among the readers. The article skillfully gains the readers' attention and generates pros and cons.

\section{English as the Dominant Language}

Sugiharto (2012) has written an opinion hoping to contribute some ideas in opposing for the English abolition issue. As he writes in his opening paragraphs, he states, "Omission of English from the curriculum is as harmful for our relationships with developed countries which value English over other foreign languages - Australia, the United States, India to name but three. Opposing English is tantamount to opposing globalization and modernity." (Par 3)

Such reason, which describes the disagreement of omission of English, reflects an anxiety that Indonesian diplomatic relations with some English speaking countries are at risk. This reason, on valuing English as a powerful language of international communication, seems to equate the importance of English with globalization and modernity deprivation, to the point that the people of any country are in a very real sense deprived if they do not know English. While there is a sense in which Sugiharto (2012) is making a valid observation, as an unqualified generalization it is false. There are lots of non-English speaking countries that make good relations with English speaking country. What is more challenging about his claim is the question of the link between non mastery of English and the globalization and modernity deprivation. There is clearly no simple causal relationship between them, but to deny that there could be any link would be to ignore the fact that English has a dominant position in science, technology, medicine, research, books and business. English has also been widely dispersed around the world, it is the official language in 83 countries/regions (ISO), spoken in 105 other countries. (nationonline, n.d.).

Sugiharto (2012) makes clear that, "it is not surprising to see that most, if not all, the comments in The Jakarta Post's readers' forum are very pro-English and full of well-worn labels such as "lingua franca", "the window of the world", "world language" and "the language of wider communication". The labels of English presented on the writing imply the author's appeal to the power of English as the dominant language. In addition, the author attempts to confirm that, "these positive attitudes to English demonstrate people's awareness of the importance of the language of global access."

The term lingua franca is an ambivalent one. In the Report on the Conference on the Teaching of English as a Second Language, held at Makarere, Uganda, in 1961, a lingua franca is defined, for the purposes of the report as "any non-English language which is widely used, or taught in schools for use, between nationals of the same country, but which is not the mother tongue at all." (Makarere Report, 1961:5). Phillipson (2003:42) says: "The restriction of lingua franca to country-internal uses is bizarre, but the placing of English in category of its own, superior to all other languages which are merely lingua francas or vernaculars, is a clear example of colonialist discourse, being used here as the neo-colonialist order was ushered in." The term is now frequently applied to dominant international languages and the tendency is to promote English as the only lingua franca which can serve modern purposes. According to Phillipson (Ibid) This discourse also puts English into a class of its own. This reinforces the dominant ideology, which presupposes that English is the most eligible language for virtually all significant purposes.

In the end of the article, when describing the benefit of his ideas, the author makes clear that his idea is an exalted ideal: "Rather than simply glorifying the values of English and telling students that learning English offers massive benefits to their future lives, it is far more urgent to help them challenge language by exploiting and appropriating it by virtue of their identities, cultural norms and values, and tradition." Although the author successfully describes the benefits of the plan, they do not adequately demonstrate that it would be workable. He also pays little attention to the possibility that it might be better to exploit Indonesian identities, cultural norms and values by means of English, instead of vice versa.

\section{English as Commodity}

In his article, Trimono (2012) claims that every government policy will always have its pros and cons. But, the classic problem with almost all government decisions is that the solution does not address the problem. The title of the article attempts to question the government's plan of eliminating English as a subject in elementary school. The author argues, "It is important to master English as it is generally used worldwide. It opens a larger network and broadens knowledge. It reflects the modernity and globalization that we should face and not avoid. In order to compete with other countries, especially our neighbors, we need to accelerate our development by empowering citizens with the communication and language skills set that is internationally accepted." This point of view underlines English as commodity, where it has economic as well as ideological aspects.

Since the plan first mentioned by The Deputy Education and Culture Minister for Education, Musliar Kasim, the teaching English in elementary school has become a controversial activity. Highlighting the author's point of view that we need to accelerate our development by empowering citizens with the communication and language skills set that is internationally accepted, it is wise if we reflect on some questions addressed by Canagarajah (1999:3): "Does English offer Third World countries a resource that will help them in their development, as Western governments and development agencies would claim? Or is it a Trojan horse, whose effect is to perpetuate their dependence?"

The article's structure was logically developed overall, with the use of short paragraphs helping the reader access the main points more easily. In his point of view, however, the author does not mention nor elaborate further the suggested ways to make English lessons more attractive. It is one thing to make good packaging English 
in Indonesia, a nation-state with a pluralistic society. It is quite another to establish such programs in a developing country with varying cultural traditions and governmental structures.

\section{The Dominance of English as Normal and Positive Phenomenon}

The third chosen is an article written by Herlina (2012). In her article, she highlights the equal rights of those less fortunate children with the children from middle to upper class to have access to the international language. She writes: "It means the government has denied those in the lower-class access to the international language which play significant role in the globalized world." A statement of this type is dangerous because it seems to describe the wide spread of English as a natural phenomenon, preventing us from understanding its negative aspects.

Even if the current tendency is to consider the dominance of English as a normal and positive phenomenon, there are some sociolinguists who have tried to find the risks connected to it. For instance, the Japanese journalist, Tsuda (2012) analyses three of these problems. The first of them is the Linguistic and communicative inequality. If English dominates communication, native speakers of English will be more able to control and manipulate advantageously a conversation than non-native speakers of English. This situation leads to hierarchical communications system in which relationships between participants are asymmetrical and contributes to maintain in a linguistic guise the gap between rich and poor. The other two types of problems, the Linguistic discrimination and social inequality and the Colonization of the consciousness, go beyond the linguistic system. (Tsuda, 2012)

\section{CONCLUSION}

The results of the study suggest that English hegemony is reflected on the readers' opinion. The reasons presented in the readers' opinion value English as a powerful language of international communication which seems to equate the importance of English with globalization and modernity. Language is part of culture, therefore equity among languages will mean also mutual respect among cultures that will not ever seen as opposed and substitutable but rather like complementary. In this manner we will have also a democratization of diplomatic and economic relationships that means a real respect of human rights. Contrary, nowadays English serves to be the language of human rights because it is the language most used during the Conferences and meetings of International Organizations such as the United Nations. But it is paradoxical that a language of human rights contributes through its diffusion, to deprive other languange, people, especially minorities, of their basic human rights, linguistic or economic, social and civil. Further research is recommended to investigate the result, for different groups in society.

\section{REFERENCES}

Canagarajah, S. (1999). Resisting Linguistic Imperialism in English Teaching. Oxford University Press.

Crystal, D., (2003). English as a Global Language. Cambridge University Press.

Goldberg, M. (n.d.). Hegemony. Rerieved from http://faculty.washington.edu/mlg/courses/definitions/hegemony.html

Herlina. (2012, Oct 22). IMO View: English vs Mother Tongues. Retrieved from http://www.thejakartapost.com/news/2012/10/22/imo-view-english-vsmother-tongues.html

Nationonline. (n.d.). Most widely spoken Languages in the World. Retrieved from http://www.nationsonline. org/oneworld/most_spoken_languages.htm

Phillipson, R. (2003). Linguistic Imperialism. Oxford University Press.

Sugiharto, S. (2012, Oct 20). Cutting a Foreign Tongue? Retrived from http:/www.thejakartapost.com/news/2012/10/20/ cutting-a-foreign-tongue.html

Tisci, R. (n.d.). Is English a language that unifies or that divides. Retrieved from http://www.academia. edu/1460923/Is_English_a_language_that_unifies or that divides.

Trimono, R. (2012, October 24). Why should we sacrifice English? Retrieved from http://www.thejakartapost. com/news/2012/10/24/your-letter-why-should-wesacrifice-english.html

Tsuda, Y. ( 2012). The Hegemony of English and Strategies for Linguistic Pluralism: Proposing the Ecology of Language Paradigm. Retrieved from http:// miresperanto.com/en/english_as_intern/hegemony_of_english.htm 